Page 1 of 14

\title{
FRACTURE MECHANICS TESTING OF TITANIUM 6AL-4V IN AF-M315E
}

\author{
J. W. Sampson and J. Martinez \\ NASA Kennedy Space Center \\ Kennedy Space Center, Florida \\ C. McLean \\ Ball Aerospace and Technologies Corp. \\ Boulder, Colorado
}

\begin{abstract}
The Green Propellant Infusion Mission (GPIM) will demonstrate the performance of AFM315E monopropellant on orbit. Flight certification requires a safe-life analysis of the titanium alloy fuel tank to ensure inherent processing flaws will not cause failure during the design life of the tank. Material property inputs for this analysis require testing to determine the stress intensity factor for environment-assisted cracking (KEAC) of Ti 6Al-4V in combination with the AF-M315E monopropellant. Testing of single-edge notched, or $\mathrm{SE}(\mathrm{B})$, specimens representing the bulk tank membrane and weld material were performed in accordance with ASTM E1681. Specimens with fatigue pre-cracks were loaded into test fixtures so that the crack tips were exposed to AF-M315E at $50^{\circ} \mathrm{C}$ for a duration of 1,000 hours. Specimens that did not fail during exposure were opened to inspect the crack surfaces for evidence of crack growth. The threshold stress intensity value, $\mathrm{K}_{\mathrm{EAC}}$, is the highest applied stress intensity that produced neither a failure of the specimen during the exposure nor showed evidence of crack growth. The threshold stress intensity factor for environment-assisted cracking of the Ti $6 \mathrm{Al}-4 \mathrm{~V}$ forged tank material was found to be at least 22 ksi $\sqrt{ }$ in and at least $31 \mathrm{ksi}$ in for the weld material when exposed to AF-M315E monopropellant.
\end{abstract}

\section{INTRODUCTION}

The Green Propellant Infusion Mission (GPIM), managed by Ball Aerospace and funded by the Space Technology Mission Directorate (STMD) at NASA Headquarters, will demonstrate the in-space performance of a new monopropellant, AF-M315E. Developed by the Air Force Research Laboratory (AFRL), AF-M315E provides a higher density and increased specific impulse relative to hydrazine. Because this hydroxylammonium nitrate blend has a lower vapor pressure than hydrazine, it does not require the same degree of personal protective equipment (PPE) during servicing. It is expected that this reduction in PPE will lower the cost of propellant handling. In flight, the propellant will be contained in a pressurized propellant tank on the GPIM satellite. A fracture mechanics analysis is required to verify the safe design life of the pressurized tank for certification by range safety. The objective of the fracture mechanics analysis is to model operating stresses so that a preexisting flaw of an assumed maximum initial size will not grow to a critical size during the service life of the propellant tank. The analysis shows that any crack large enough to cause tank failure would have been seen during inspection. Inputs for this analysis include the crack growth properties of the tank material when exposed to the propellant.

Since NASA's Apollo program, titanium alloy Ti $6 \mathrm{Al}-4 \mathrm{~V}$ has been the material of choice for propellant pressure vessels because of its high strength-to-weight ratio and its resistance to corrosion. The structural integrity of $\mathrm{Ti} 6 \mathrm{Al}-4 \mathrm{~V}$ pressure vessels has been studied since the late

\section{EAR 99 -- NO LICENSE REQUIRED}

The information contained in the document is technical in content, but not technical data as defined by the International Traffic in Arms Regulations (ITAR) or the Export Administration Regulations (EAR), and therefore is EAR $99 \mathrm{NLR}$, no export license required. [General Prohibition Six (Embargo) applies to all items subject to the EAR, (i.e., items on the CCL and within EAR $99 \mathrm{NLR}$ ). You may not make an export or re-export contrary to the provisions of part 746 (Embargos and Other Special Controls) of the EAR and 22 CFR part 126.1 of the ITAR].

Reference EDR \#1631066: NASA KSC Export Control Office, 321-867-9209 
1960s. Included in these studies was the sustained load flaw growth of the Ti $6 \mathrm{Al}-4 \mathrm{~V}$ and welds of Ti $6 \mathrm{Al}-4 \mathrm{~V}$ alloy. Crack growth testing was carried out using common propellants and oxidizers in use during the time period, which included hydrazine, monomethyhydrazine, Aerozine 50, and nitrogen tetroxide. The threshold stress intensity factor for environment-assisted crack growth (KEAC) was determined through test. Since then, all pressurized propellant tanks used on NASA spacecraft have used these combinations of tank material and propellants. With the development of AF-315E monopropellant, testing is required to determine the KEAC of the titanium tank when exposed to this new monopropellant.

The testing documented herein investigates the threshold stress intensity factor for environment-assisted cracking (KEAC) of Ti 6AI-4V in combination with AF-M315E for input into a fracture mechanics analysis. A team of engineers at NASA's Kennedy Space Center (KSC), ATK Space Systems, Air Force Research Laboratories (AFRL) at Edwards Air Force Base, and Ball Aerospace have developed procedures and test hardware to perform this testing. Because the flight tank is fabricated by welding two hemispherical forgings into a sphere, testing will include specimens representing the bulk forging and the weld. Testing of the weld material will be especially important because the design of the tank precludes the possibility of post weld aging heat treatments. Testing will be performed according to ASTM E1681, Standard Test Method for Determining Threshold Intensity Factor for Environment-Assisted Cracking of Metallic Materials. Upon completion of the testing, the resultant stress intensity threshold values will be provided to ATK for analysis using NASGRO ${ }^{1}$ fracture analysis software. Historically NASGRO fracture analysis has been performed using design recommendations for Ti $6 \mathrm{Al}-4 \mathrm{~V}$ forgings and un-aged welds by Lewis and Kenny ${ }^{2}$. This reference documented testing of uniaxially loaded fracture mechanics specimens containing part-through cracks, where the crack tips were exposed to hydrazine under a sustained load for 24 hours.

\section{PROCEDURES}

The purpose of the testing is to produce stress intensity threshold values for Ti $6 \mathrm{Al}-4 \mathrm{~V}$ in AF-M315E monopropellant in accordance with ASTM E1681. For this test single-edge bend specimens, annotated as $\mathrm{SE}(\mathrm{B})$ specimens, were fatigued to grow sharp crack tips. $\mathrm{SE}(\mathrm{B})$ specimens were loaded into test fixtures so that the crack tips were exposed to the propellant at $50^{\circ} \mathrm{C}$ for a duration of 1,000 hours. This temperature represents the highest temperature that the flight tank is expected to experience on orbit and the worst case for corrosive effects of the monopropellant. The duration of the test was dictated by ASTM E1681. Upon completion of the exposure, $\mathrm{SE}(\mathrm{B})$ specimens that did not fail were marked with post-test fatigue cracks. Specimens were then opened to inspect the crack surfaces for evidence of growth during environmental exposure. The threshold stress intensity value, $\mathrm{K}_{\mathrm{EAC}}$, is the highest applied stress intensity that produced neither a failure of the specimens during the exposure nor showed evidence of crack growth.

\section{SPECIMEN PREPARATION}

The test material, shown in Fig. 1 included a Ti $6 \mathrm{Al}-4 \mathrm{~V}$ forging and a weld verification ring. The Ti $6 \mathrm{Al}-4 \mathrm{~V}$ forging was provided in the solution treated and aged (STA) condition to represent the bulk tank membrane. The weld verification ring was unaged and represented the $\mathrm{Ti}$ $6 \mathrm{Al}-4 \mathrm{~V}$ weld on the GPIM tank. 

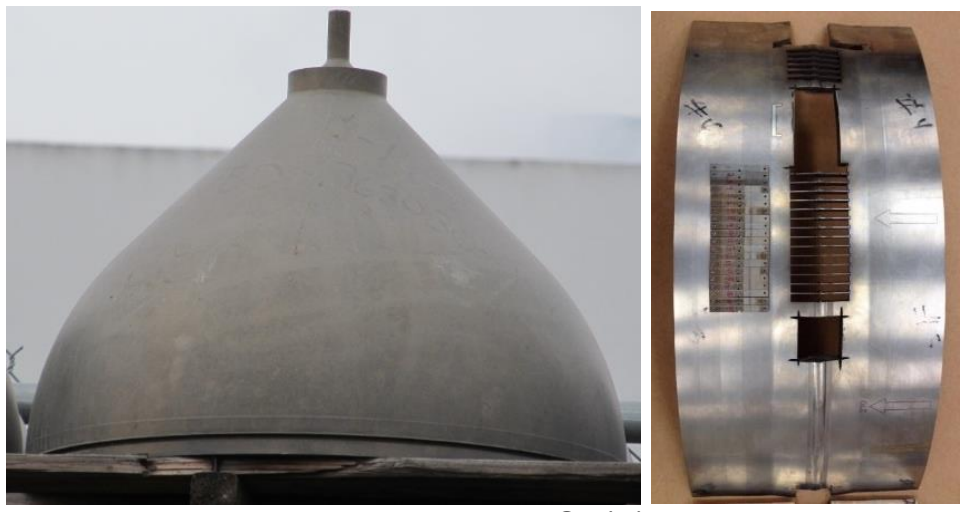

Figure 1. Ti 6Al-4V material. SE(B) specimens were machined from the bulk forging (left) and weld verification ring (right).

SE(B) specimens were machined to the dimensions shown in Fig. 2. Bulk specimens were cut from the forging so that cracks would grow in the L-S direction, which corresponds to crack propagation from hoop stress in a pressurized tank. Weld specimens were cut from the weld ring with the crack in the through-thickness plane and growing parallel to the direction the weld solidification. Specimens were cut using a wire electrical discharge machine (EDM). The faces of the specimen were ground to remove the recast layer and polished to enable view of the pre-cracks on the sidewall of the specimen.

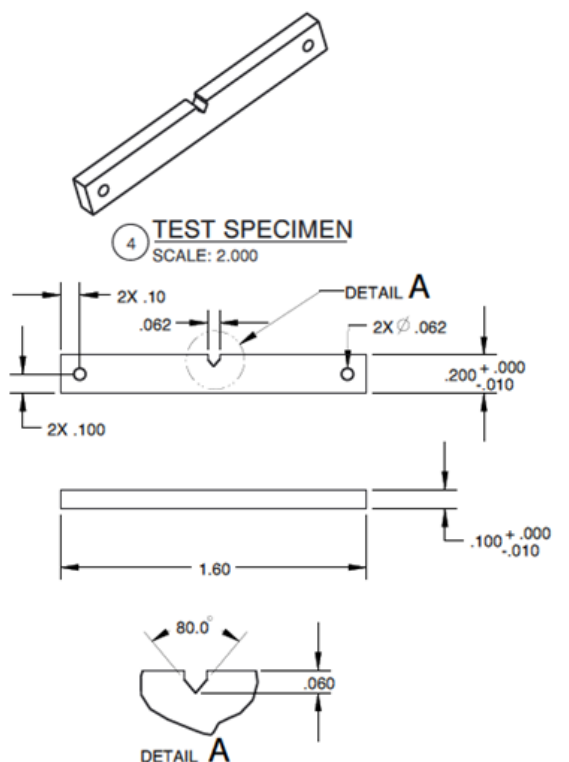

Figure 2. Specimen drawing. Single edge bend specimen, $\mathrm{SE}(\mathrm{B})$, dimensions in inches.

\section{TENSILE, METALLOGRAPHY, AND MICROHARDNESS}

It was necessary to determine the tensile properties, specifically the yield strength, of the materials in order to calculate the validity of the fracture toughness and threshold stress intensity results. Tensile properties were determined referencing ASTM E8 for both the bulk material and the weld. Sub-size specimens were cut using the wire EDM. Gauge length was reduced from 1.0 inches to 0.75 inches because of the size of the sections available for testing. Bulk specimens were tested in the wrought direction and weld specimens were tested perpendicular to the direction of the weld solidification.

Metallographic specimens were prepared from the weld ring per ASTM E3. This enabled machining of the $S E(B)$ specimens so that the notch and crack were contained in the weld metal. To locate the heat affected zone (HAZ) from welding, Vickers microhardness testing was performed with a 500 gram-force load in accordance to ASTM E384.

\section{FATIGUE PRE-CRACKING}

Fatigue pre-cracks were induced at the notched $S E(B)$ specimens using an MTS 810 servo-hydraulic load frame. A three-point bending test fixture in Fig. 3 was configured referencing ASTM E399 Annex 2 with a load span of 0.8 inch. Cracks were grown using a force shedding method with stress ratio, $R$, of 0.1 . Depending on the fatigue crack length, the maximum load in

\section{EAR 99 -- NO LICENSE REQUIRED}

The information contained in the document is technical in content, but not technical data as defined by the International Traffic in Arms Regulations (ITAR) or the Export Administration Regulations (EAR), and therefore is EAR $99 \mathrm{NLR}$, no export license required. [General Prohibition Six (Embargo) applies to all items subject to the EAR, (i.e., items on the CCL and within EAR $99 \mathrm{NLR}$ ). You may not make an export or re-export contrary to the provisions of part 746 (Embargos and Other Special Controls) of the EAR and 22 CFR part 126.1 of the ITAR]. 
each cycle was either 110, 90, or $70 \mathrm{lb}$. Using Eq. (1), the stress intensity was never above 15 ksi $\sqrt{ }$ in to prevent a plastic deformation at the crack tip. The fatigue crack length was monitored on the sidewalls of the specimen, as is shown in Fig. 3, using a Keyence digital stereomicroscope. The target length for the fatigue cracks was $0.10 \pm 0.01 \mathrm{inch}$. Specimens were cleaned prior to loading in the test fixtures per ASTM G1.

$$
K=\frac{P S}{B W^{3 / 2}} * 3 \sqrt{\frac{a}{W}} * \frac{1.99-\left(\frac{a}{W}\right) *\left(1-\frac{a}{W}\right) *\left[\left(2.15-3.93\left(\frac{a}{W}\right)+2.7\left(\frac{a}{W}\right)^{2}\right]\right.}{2 *\left(1+2 * \frac{a}{W}\right) *\left(1-\frac{a}{W}\right)^{3 / 2}}(1)
$$
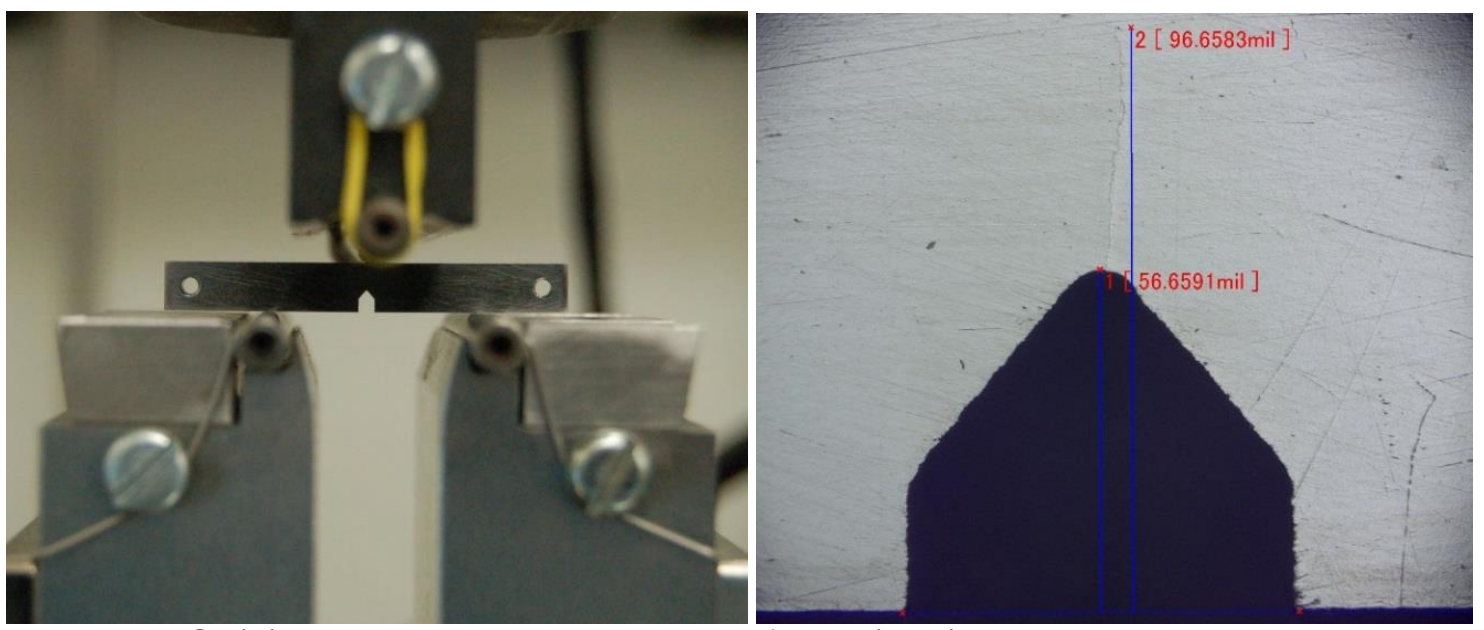

Figure 3. $\mathrm{SE}(\mathrm{B})$ specimens in three-point bend fixture (right) and crack length measurement with a stereomicroscope (left).

\section{FRACTURE TOUGHNESS}

Fracture toughness testing was performed on specimens representing both the bulk tank material and the weld material in accordance with ASTM E399. Results were used to design and build test fixtures and weights for the threshold stress intensity testing that followed.

\section{PROPELLANT EXPOSURE}

Air Force Research Laboratory (AFRL) at Edwards Air Force Base designed test fixtures for loading the specimens while they are exposed to the AF-M315E monopropellant in an oven set to $50^{\circ} \mathrm{C}$ for 1,000 hours. A cantilever bending apparatus shown in Figure 4 was designed to apply stress intensities up to $80 \%$ of the fracture toughness. The fixture was designed such that the notch and crack were surrounded by a flask, which contained the AF-M315E monopropellant. The flask contained through holes for the specimen that were sealed with a rubberized sealant. The test fixtures were designed to hold a set of twelve specimens that were dead weight loaded, exposed to the propellant, and placed in an oven for the duration of the test.

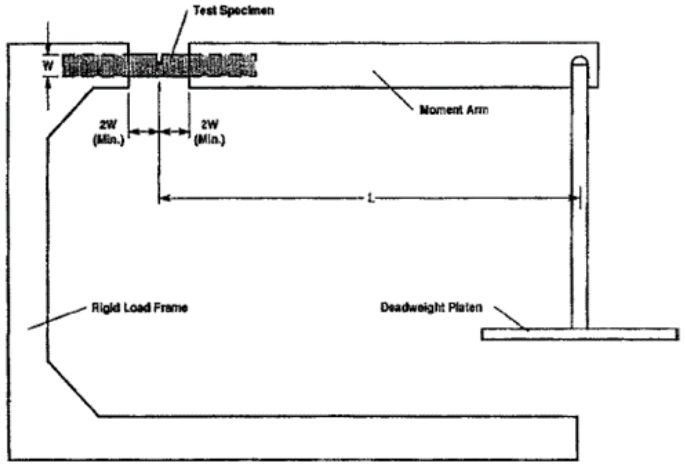

Figure 4. Loading Fixture from ASTM E1681. 


\section{POST TEST ANALASIS}

After exposure, the fracture surfaces were prepared for viewing with a stereomicroscope. The pre-cracked fracture surface and any crack growth form the threshold testing were marked with an oxide coating in an oven set to $300^{\circ} \mathrm{C}$ for 30 minutes. Post-test fatigue cracks were then grown using same the pre-cracking fatigue method. This allowed for crack growth during the environmental exposure to be framed between the pre- and post-fatigue cracks. Test specimens were then broken open to view the fracture surfaces. The initial fatigue crack length was measured and the stress intensity of each specimen was calculated using Eq. (2) from ASTM E1681.

$$
\begin{gathered}
K=\frac{W_{a} L_{a}+W_{t} L}{B W^{3 / 2}} * \frac{6\left(\frac{a}{W}\right)^{1 / 2}}{\left(1-\frac{a}{W}\right)^{3 / 2}} *\left\{1.9878-1.3253\left(\frac{a}{W}\right)+\left(1-\frac{a}{W}\right)\left(\frac{a}{W}\right)\left[-3.8308+10.1081\left(\frac{a}{W}\right)-\right.\right. \\
\left.\left.17.9415\left(\frac{a}{W}\right)^{2}+16.8282\left(\frac{a}{W}\right)^{3}-6.2241\left(\frac{a}{W}\right)^{4}\right]\right\}
\end{gathered}
$$

\section{RESULTS AND DISCUSSION}

Three rounds of $\mathrm{SE}(\mathrm{B})$ specimens were exposed to the AF-M315E monopropellant for the duration of the 1,000-hour test. The test specimens representing both the bulk and weld materials were tested at a range of effective $K_{E A C}$ values. After testing, specimens were evaluated to the requirements of ASTM E1681.

\section{TENSILE PROPERTIES, METALLOGRAPHY, AND MICROHARDNESS}

Tensile results of the bulk material and weld are displayed in Table 1. The yield strength of the bulk averaged $156 \mathrm{ksi}$ and the tensile strength was $166 \mathrm{ksi}$. The yield strength of the material in the weld averaged $140 \mathrm{ksi}$ with a tensile strength of $154 \mathrm{ksi}$. The micrograph of the weld, along with the Vickers microhardness numbers are shown in Fig. 5.

Table 1. Results of Tensile Testing.

Yield
Strength- Tensile Elongation

Thickness Width Gauge Maximum Offset 0.2 Strength at Failure

\begin{tabular}{ccccccccc} 
Material & Specimen & (in) & (in) & Length (in) & Load (lbf) & $\%(\mathrm{ksi})$ & $(\mathrm{ksi})$ & $(\%)$ \\
\hline Bulk & B-T1 & 0.0960 & 0.2340 & 0.6504 & 3727 & 155.9 & 165.9 & 15.7 \\
\hline Bulk & B-T2 & 0.0960 & 0.2450 & 0.6728 & 3881 & 156.8 & 165.0 & 15.5 \\
\hline Weld & W-T1 & 0.0860 & 0.2460 & 0.6415 & 3256 & 139.0 & 153.9 & 4.0 \\
\hline Weld & W-T2 & 0.0845 & 0.2460 & 0.6455 & 3185 & 140.7 & 153.2 & 5.2 \\
\hline Weld & W-T3 & 0.0850 & 0.2460 & 0.6645 & 3213 & 141.3 & 153.7 & 4.6 \\
\hline
\end{tabular}

\section{EAR 99 -- NO LICENSE REQUIRED}

The information contained in the document is technical in content, but not technical data as defined by the International Traffic in Arms Regulations (ITAR) or the Export Administration Regulations (EAR), and therefore is EAR $99 \mathrm{NLR}$, no export license required. [General Prohibition Six (Embargo) applies to all items subject to the EAR, (i.e., items on the CCL and within EAR $99 \mathrm{NLR}$ ). You may not make an export or re-export contrary to the provisions of part 746 (Embargos and Other Special Controls) of the EAR and 22 CFR part 126.1 of the ITAR]. 


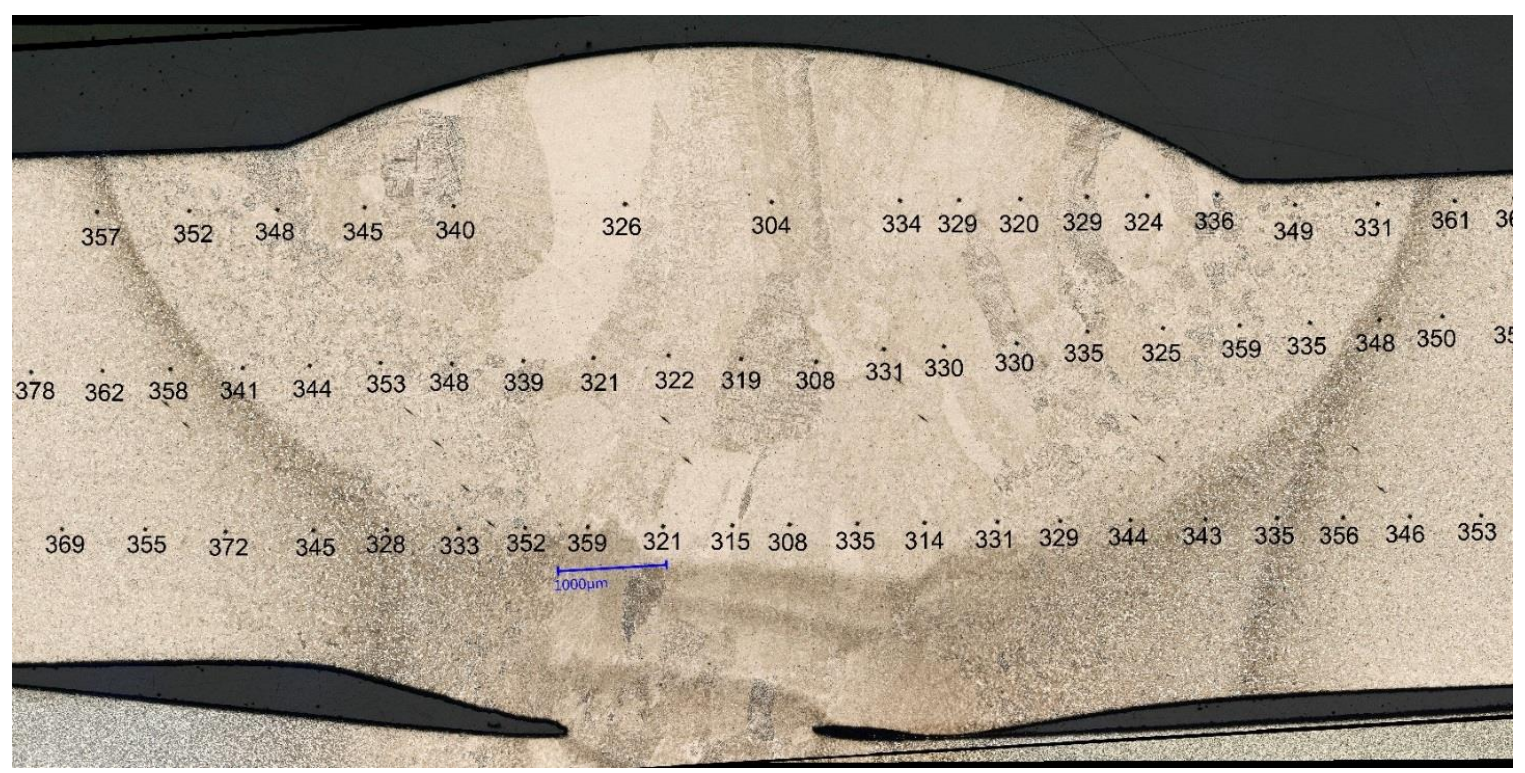

Figure 5. Micrograph of weld. Polished section of weld etched with Kroll's reagent. Vickers microhardness (HV) numbers tested with a 500 gram-force load.

\section{FRACTURE TOUGHNESS RESULTS}

Fracture toughness test results are listed in Table 3 . The plane-strain validity criteria in ASTM E399 section 9.1.4 was satisfied for neither the bulk nor the weld specimens. Therefore results could not be reported as the plane-strain fracture toughness, $\mathrm{K}_{\mathrm{lc}}$, but rather the conditional fracture toughness result, $\mathrm{K}_{\mathrm{Q}}$. Additionally, the weld specimens failed ASTM E399 section 9.1.3 criteria because of plastic deformation at the crack tip during failure. Further testing of fracture toughness for these weld specimens should be according to ASTM E 1820 to calculate the Jic, critical elastic-plastic fracture toughness. The average $\mathrm{K}_{\mathrm{Q}}$ for the bulk specimens was $45.0 \mathrm{ksi} \sqrt{ } \mathrm{in}$ and the weld specimens was $49.0 \mathrm{ksi}$ in.

Table 2. Results of fracture toughness testing. Fracture toughness was tested per ASTM E399.

\begin{tabular}{ccccccc}
\hline Material & Specimen & $\begin{array}{c}\text { Initial Crack } \\
\text { Length, } \mathrm{a}_{0} \\
(\mathrm{in})\end{array}$ & $\begin{array}{c}\mathrm{P}_{\mathrm{q}} \\
(\mathrm{lbf})\end{array}$ & $\begin{array}{c}\mathrm{P}_{\max } \\
(\mathrm{lbf})\end{array}$ & $\mathrm{P}_{\max } / \mathrm{P}_{\mathrm{q}}$ & $\begin{array}{c}\text { Toughness, KQ } \\
(\mathrm{ksi} \sqrt{ } \text { in) }\end{array}$ \\
\hline Bulk & B01 & 0.1085 & 143.2 & 145.8 & 1.02 & $45.4^{*}$ \\
\hline Bulk & B02 & 0.1037 & 154.6 & 161.7 & 1.05 & $45.1^{*}$ \\
\hline Bulk & B03 & 0.0986 & 166.1 & 169.5 & 1.02 & $44.5^{*}$ \\
\hline Weld & W01 & 0.0890 & 214.1 & 268.7 & 1.26 & $49.8 \dagger$ \\
\hline Weld & W02 & 0.1033 & 172.2 & 216.8 & 1.26 & $49.5 \dagger$ \\
\hline Weld & W03 & 0.0935 & 212.1 & 257.7 & 1.21 & $50.0 \dagger$ \\
\hline Weld & W04 & 0.1023 & 166.1 & 208.8 & 1.26 & $46.6 \dagger$ \\
\hline
\end{tabular}

* Invalid according to section 9.1.4 of test method ASTM E399

$\dagger \quad$ Invalid according to sections 9.1.3 and 9.1.4 of test method ASTM E399

\section{THRESHOLD STRESS INTENSITY FACTOR RESULTS}

Results of the stress intensity threshold testing per ASTM E1681 are listed in Table 4. Bulk and weld specimens failed ASTM E1681 section 9.3.1 validity check for KIEAC where Eq. (3) is less than $\mathrm{B}, \mathrm{a} 0$, and $\mathrm{W}-\mathrm{a} 0$. A less restrictive validity check for $\mathrm{K}_{\mathrm{EAC}}$ was calculated per ASTM E1681 section 9.3.2, where Eq. (4) is less W-a . The bulk material passes this criteria at stress 
intensities less than $43 \mathrm{ksi} V \mathrm{in}$ and the weld specimens pass this criteria at stress intensities less than $37 \mathrm{ksi} \backslash \mathrm{in}$. Plane-strain conditions would have been ideal but could not be achieved with these specimens due to the thickness constraints of the material provide for this test.

$$
\begin{aligned}
& 2.5\left(\frac{K_{E A C}}{\sigma_{Y S}}\right)^{2} \\
& \frac{4}{\pi}\left(\frac{K_{E A C}}{\sigma_{Y S}}\right)^{2}
\end{aligned}
$$

Eight of the twelve specimens from the first round of testing failed during dead weight load application. The remaining four specimens showed evidence of crack growth at the fatigue crack. Magnified photographs of some fracture surfaces from the first round of testing are shown in Fig. 6.

The second round of testing included twelve specimens. No specimen failed and after post-test evaluation and no crack growth was detected in any of the twelve. Three of eight specimens representing the weld materials were not exposed to AF-M315E and were used as a baseline, but are not documented in this report. Magnified photographs of some facture surfaces from the second round of testing are shown in Fig. 7.

The third round of testing included twelve specimens. No specimen failed and after posttest evaluation and no crack growth was detected in any of the twelve specimens. Magnified photographs of some facture surfaces from the third round of testing are shown in Fig. 8.

\section{EAR 99 -- NO LICENSE REQUIRED}

The information contained in the document is technical in content, but not technical data as defined by the International Traffic in Arms Regulations (ITAR) or the Export Administration Regulations (EAR), and therefore is EAR $99 \mathrm{NLR}$, no export license required. [General Prohibition Six (Embargo) applies to all items subject to the EAR, (i.e., items on the CCL and within EAR $99 \mathrm{NLR}$ ). You may not make an export or re-export contrary to the provisions of part 746 (Embargos and Other Special Controls) of the EAR and 22 CFR part 126.1 of the ITAR]. 
Table 3. Results from first round of stress intensity threshold testing.

\begin{tabular}{|c|c|c|c|c|c|c|}
\hline Material & Specimen & $\begin{array}{l}\text { Thick- } \\
\text { ness, } \\
\text { B (in) }\end{array}$ & $\begin{array}{l}\text { Width, } \\
\text { W (in) }\end{array}$ & $\begin{array}{l}\text { Initial } \\
\text { Crack } \\
\text { Length, } \\
\text { ao (in) }\end{array}$ & $\begin{array}{l}\text { Stress } \\
\text { Intensity, } \\
\text { KEAC }_{\text {EAC }} \\
\text { (ksi } \sqrt{\text { in })}\end{array}$ & Test Result \\
\hline Bulk & B08 & 0.0955 & 0.1970 & 0.0930 & 36.4 & $\begin{array}{l}\text { Crack growth detected after } \\
1000 \text { hours exposure to AF- } \\
\text { M315E at } 50^{\circ} \mathrm{C}\end{array}$ \\
\hline Bulk & B16 & 0.0950 & 0.1965 & 0.0942 & 37.6 & $\begin{array}{l}\text { Crack growth detected after } \\
1000 \text { hours exposure to AF- } \\
\text { M315E at } 50^{\circ} \mathrm{C}\end{array}$ \\
\hline Bulk & B20 & 0.0950 & 0.1965 & 0.0965 & 38.8 & $\begin{array}{l}\text { Crack growth detected after } \\
1000 \text { hours exposure to AF- } \\
\mathrm{M} 315 \mathrm{E} \text { at } 50^{\circ} \mathrm{C}\end{array}$ \\
\hline Bulk & B06 & 0.0950 & 0.1970 & 0.0924 & 38.9 & $\begin{array}{l}\text { Immediate fracture upon } \\
\text { loading }\end{array}$ \\
\hline Bulk & B11 & 0.0950 & 0.1970 & 0.0945 & 40.2 & $\begin{array}{l}\text { Crack growth detected after } \\
1000 \text { hours exposure to AF- } \\
\mathrm{M} 315 \mathrm{E} \text { at } 50^{\circ} \mathrm{C}\end{array}$ \\
\hline Bulk & B15 & 0.0950 & 0.1970 & 0.0984 & 42.6 & $\begin{array}{l}\text { Immediate fracture upon } \\
\text { loading }\end{array}$ \\
\hline Bulk & B14 & 0.0950 & 0.1960 & 0.0956 & 44.3 & $\begin{array}{l}\text { Immediate fracture upon } \\
\text { loading }\end{array}$ \\
\hline Bulk & B12 & 0.0955 & 0.1970 & 0.0953 & 46.0 & $\begin{array}{l}\text { Immediate fracture upon } \\
\text { loading }\end{array}$ \\
\hline Bulk & B19 & 0.0950 & 0.1960 & 0.0956 & 47.1 & $\begin{array}{l}\text { Immediate fracture upon } \\
\text { loading }\end{array}$ \\
\hline Bulk & B10 & 0.0950 & 0.1965 & 0.0969 & 47.7 & $\begin{array}{l}\text { Immediate fracture upon } \\
\text { loading }\end{array}$ \\
\hline Bulk & B22 & 0.0950 & 0.1965 & 0.1010 & 47.9 & $\begin{array}{l}\text { Fracture approx. } 5 \text { minutes } \\
\text { after loading }\end{array}$ \\
\hline Bulk & B18 & 0.0955 & 0.1965 & 0.1074 & 52.8 & $\begin{array}{l}\text { Immediate fracture upon } \\
\text { loading }\end{array}$ \\
\hline
\end{tabular}



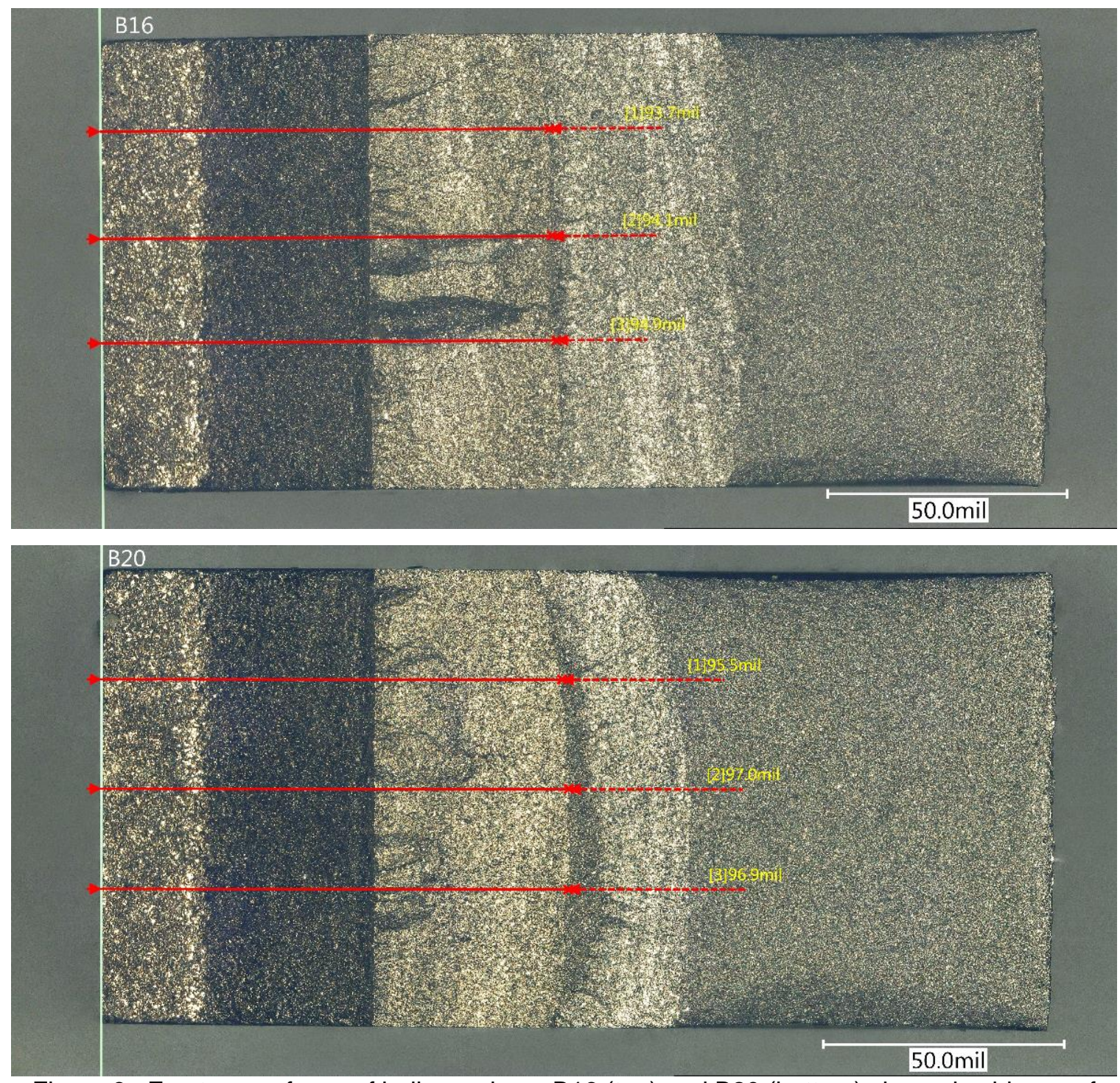

Figure 6. Fracture surfaces of bulk specimen B16 (top) and B20 (bottom) showed evidence of crack growth after 1,000 hours of exposure to AF-M315E at $50^{\circ} \mathrm{C}$. The length of the fatigued precrack is annotated.

\section{EAR 99 -- NO LICENSE REQUIRED}

The information contained in the document is technical in content, but not technical data as defined by the International Traffic in Arms Regulations (ITAR) or the Export Administration Regulations (EAR), and therefore is EAR $99 \mathrm{NLR}$, no export license required. [General Prohibition Six (Embargo) applies to all items subject to the EAR, (i.e., items on the CCL and within EAR 99 NLR). You may not make an export or re-export contrary to the provisions of part 746 (Embargos and Other Special Controls) of the EAR and 22 CFR part 126.1 of the ITAR]. 
Table 4. Results from second round of stress intensity threshold testing.

\begin{tabular}{|c|c|c|c|c|c|c|}
\hline Material & Specimen & $\begin{array}{l}\text { Thick- } \\
\text { ness, } \\
\text { B (in) }\end{array}$ & $\begin{array}{l}\text { Height, } \\
\text { W (in) }\end{array}$ & $\begin{array}{l}\text { Initial } \\
\text { Crack } \\
\text { Length, } \\
\text { ao (in) }\end{array}$ & 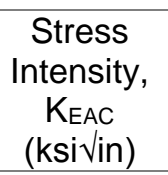 & Test Result \\
\hline Bulk & B26 & 0.0950 & 0.1970 & 0.1045 & 22.0 & $\begin{array}{l}\text { No failure or crack growth after } \\
1,000 \text { hours of exposure to AF- } \\
\text { M315E at } 50^{\circ} \mathrm{C}\end{array}$ \\
\hline Bulk & B27 & 0.0950 & 0.1970 & 0.1038 & 22.5 & $\begin{array}{l}\text { No failure or crack growth after } \\
1,000 \text { hours of exposure to AF- } \\
\text { M315E at } 50^{\circ} \mathrm{C}\end{array}$ \\
\hline Bulk & B28 & 0.0950 & 0.1965 & 0.0979 & 21.6 & $\begin{array}{l}\text { No failure or crack growth after } \\
1,000 \text { hours of exposure to AF- } \\
\text { M315E at } 50^{\circ} \mathrm{C}\end{array}$ \\
\hline Bulk & B29 & 0.0950 & 0.1975 & 0.1036 & 22.1 & $\begin{array}{l}\text { No failure or crack growth after } \\
1,000 \text { hours of exposure to AF- } \\
\text { M315E at } 50^{\circ} \mathrm{C}\end{array}$ \\
\hline Weld & W08 & 0.0910 & 0.1980 & 0.1033 & 30.8 & $\begin{array}{l}\text { No failure or crack growth after } \\
1,000 \text { hours of exposure to AF- } \\
\text { M315E at } 50^{\circ} \mathrm{C}\end{array}$ \\
\hline Weld & W10 & 0.0920 & 0.1980 & 0.1089 & 32.4 & $\begin{array}{l}\text { No failure or crack growth after } \\
1,000 \text { hours of exposure to AF- } \\
\text { M315E at } 50^{\circ} \mathrm{C}\end{array}$ \\
\hline Weld & W12 & 0.0930 & 0.1990 & 0.1040 & 31.2 & $\begin{array}{l}\text { No failure or crack growth after } \\
1,000 \text { hours of exposure to AF- } \\
\text { M315E at } 50^{\circ} \mathrm{C}\end{array}$ \\
\hline Weld & W13 & 0.0915 & 0.1980 & 0.1019 & 31.4 & $\begin{array}{l}\text { No failure or crack growth after } \\
1,000 \text { hours of exposure to AF- } \\
\mathrm{M} 315 \mathrm{E} \text { at } 50^{\circ} \mathrm{C}\end{array}$ \\
\hline Weld & W14 & 0.0920 & 0.1985 & 0.1050 & 30.7 & $\begin{array}{l}\text { No failure or crack growth after } \\
1,000 \text { hours of exposure to AF- } \\
\text { M315E at } 50^{\circ} \mathrm{C}\end{array}$ \\
\hline
\end{tabular}



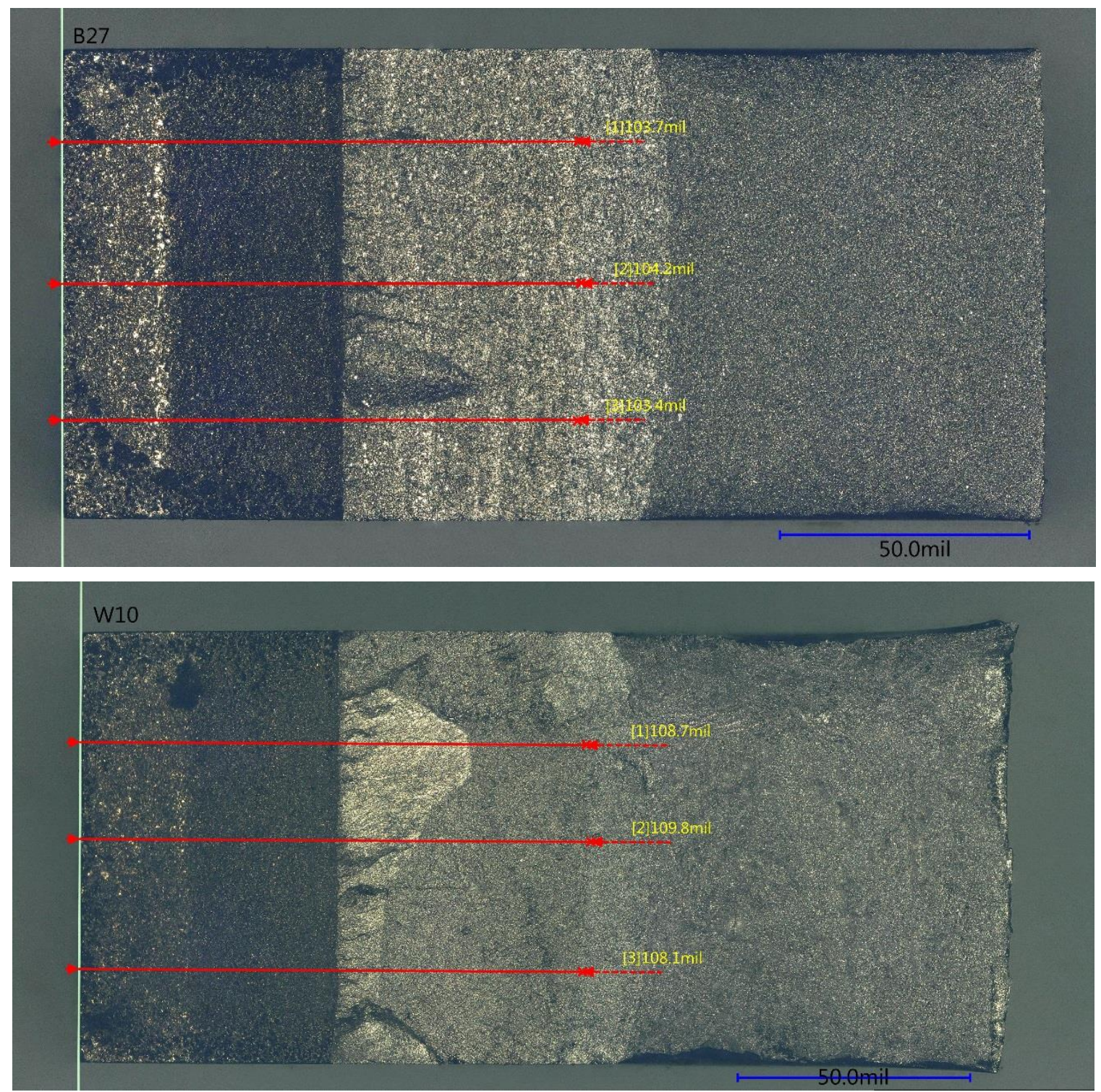

Figure 7. Fracture surfaces of bulk specimen B27 (top) and weld specimen W10 (bottom). There was no crack growth after 1,000 hours of exposure to AF-M315E at $50^{\circ} \mathrm{C}$. The length of the fatigued pre-crack is annotated.

\section{EAR 99 -- NO LICENSE REQUIRED}

The information contained in the document is technical in content, but not technical data as defined by the International Traffic in Arms Regulations (ITAR) or the Export Administration Regulations (EAR), and therefore is EAR $99 \mathrm{NLR}$, no export license required. [General Prohibition Six (Embargo) applies to all items subject to the EAR, (i.e., items on the CCL and within EAR 99 NLR). You may not make an export or re-export contrary to the provisions of part 746 (Embargos and Other Special Controls) of the EAR and 22 CFR part 126.1 of the ITAR]. 
Table 5. Results from third round of stress intensity threshold testing.

\begin{tabular}{|c|c|c|c|c|c|c|}
\hline Material & Specimen & $\begin{array}{l}\text { Thick- } \\
\text { ness, } \\
\text { B (in) }\end{array}$ & $\begin{array}{l}\text { Height, } \\
\text { W (in) }\end{array}$ & $\begin{array}{c}\text { Initial } \\
\text { Crack } \\
\text { Length, } \\
\text { ao (in) }\end{array}$ & $\begin{array}{c}\text { Stress } \\
\text { Intensity, } \\
\text { KEAC }_{\text {EAC }} \\
\text { (ksi } \sqrt{ } \text { in) }\end{array}$ & Test Result \\
\hline Bulk & B31 & 0.0840 & 0.1955 & 0.1034 & 21.6 & $\begin{array}{l}\text { No failure or crack growth after } \\
1,000 \text { hours of exposure to } A F- \\
\text { M } 315 \mathrm{E} \text { at } 50^{\circ} \mathrm{C}\end{array}$ \\
\hline Bulk & B32 & 0.0835 & 0.1950 & 0.1049 & 22.9 & $\begin{array}{l}\text { No failure or crack growth after } \\
1,000 \text { hours of exposure to } A F- \\
\text { M } 315 \mathrm{E} \text { at } 50^{\circ} \mathrm{C}\end{array}$ \\
\hline Bulk & B33 & 0.0890 & 0.1960 & 0.1011 & 22.7 & $\begin{array}{l}\text { No failure or crack growth after } \\
1,000 \text { hours of exposure to } A F- \\
\text { M } 315 \mathrm{E} \text { at } 50^{\circ} \mathrm{C}\end{array}$ \\
\hline Bulk & B34 & 0.0880 & 0.1970 & 0.1027 & 21.8 & $\begin{array}{l}\text { No failure or crack growth after } \\
1,000 \text { hours of exposure to } \mathrm{AF} \\
\mathrm{M} 315 \mathrm{E} \text { at } 50^{\circ} \mathrm{C}\end{array}$ \\
\hline Bulk & B35 & 0.0875 & 0.1980 & 0.1023 & 21.3 & $\begin{array}{l}\text { No failure or crack growth after } \\
1,000 \text { hours of exposure to } A F \\
\text { M } 315 \mathrm{E} \text { at } 50^{\circ} \mathrm{C}\end{array}$ \\
\hline Bulk & B36 & 0.0875 & 0.1965 & 0.1046 & 21.1 & $\begin{array}{l}\text { No failure or crack growth after } \\
1,000 \text { hours of exposure to } A F- \\
\text { M315E at } 50^{\circ} \mathrm{C}\end{array}$ \\
\hline Weld & W22 & 0.0930 & 0.1990 & 0.1055 & 30.5 & $\begin{array}{l}\text { No failure or crack growth after } \\
1,000 \text { hours of exposure to } \mathrm{AF} \\
\mathrm{M} 315 \mathrm{E} \text { at } 50^{\circ} \mathrm{C}\end{array}$ \\
\hline Weld & W23 & 0.0915 & 0.1980 & 0.0950 & 28.7 & $\begin{array}{l}\text { No failure or crack growth after } \\
1,000 \text { hours of exposure to } A F \\
\text { M } 315 \mathrm{E} \text { at } 50^{\circ} \mathrm{C}\end{array}$ \\
\hline Weld & W24 & 0.0920 & 0.1985 & 0.0994 & 29.2 & $\begin{array}{l}\text { No failure or crack growth after } \\
1,000 \text { hours of exposure to } A F \\
\text { M } 315 \mathrm{E} \text { at } 50^{\circ} \mathrm{C}\end{array}$ \\
\hline Weld & W25 & 0.0925 & 0.1980 & 0.1067 & 31.0 & $\begin{array}{l}\text { No failure or crack growth after } \\
1,000 \text { hours of exposure to } A F- \\
\text { M } 315 \mathrm{E} \text { at } 50^{\circ} \mathrm{C}\end{array}$ \\
\hline Weld & W27 & 0.0925 & 0.1990 & 0.1081 & 32.3 & $\begin{array}{l}\text { No failure or crack growth after } \\
1,000 \text { hours of exposure to } A F \\
\text { M } 315 \mathrm{E} \text { at } 50^{\circ} \mathrm{C}\end{array}$ \\
\hline Weld & W26 & 0.0920 & 0.1985 & 0.1048 & 30.8 & $\begin{array}{l}\text { No failure or crack growth after } \\
1,000 \text { hours of exposure to } A F \\
\text { M } 315 \mathrm{E} \text { at } 50^{\circ} \mathrm{C}\end{array}$ \\
\hline
\end{tabular}



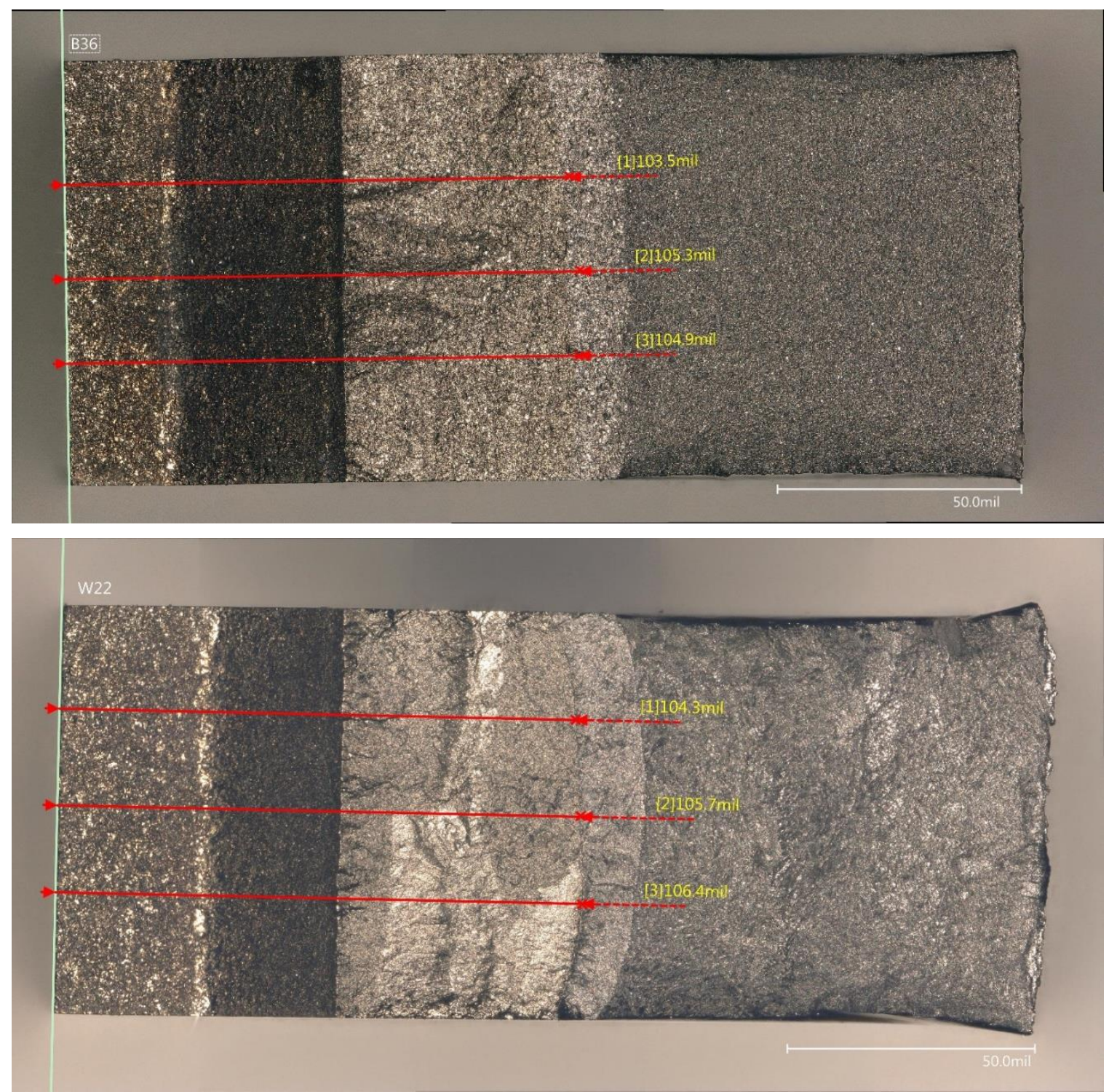

Figure 8. Fracture surfaces of bulk specimen B36 (top) and weld specimen W22 (bottom). There was no crack growth after 1,000 hours of exposure to AF-M315E at $50^{\circ} \mathrm{C}$. The length of the fatigued pre-crack is annotated.

\section{EAR 99 -- NO LICENSE REQUIRED}

The information contained in the document is technical in content, but not technical data as defined by the International Traffic in Arms Regulations (ITAR) or the Export Administration Regulations (EAR), and therefore is EAR $99 \mathrm{NLR}$, no export license required. [General Prohibition Six (Embargo) applies to all items subject to the EAR, (i.e., items on the CCL and within EAR 99 NLR). You may not make an export or re-export contrary to the provisions of part 746 (Embargos and Other Special Controls) of the EAR and 22 CFR part 126.1 of the ITAR]. 


\section{SUMMARY AND CONCLUSIONS}

The threshold stress intensity factor for environment-assisted cracking was determined for titanium alloy propellant tanks when exposed to AF-M315E monopropellant. Material representing the Ti $6 \mathrm{Al}-4 \mathrm{~V}$ tank forging was found to have a KEAC of at least $22 \mathrm{ksi} \sqrt{ } \mathrm{in}$, and the weld material was found to be at least $31 \mathrm{ksi}$ in. Plane-strain conditions would have been ideal but could not be achieved due to the thickness constraints of the material provided for testing. However, the bulk forging used to produce these test specimens is considerably thicker than the tank wall of the GPIM flight tank. Since fracture toughness decreases as material thickness and width increases ${ }^{3}$, the threshold stress intensity results are considered conservative for analysis of the GPIM propellant tank.

\section{FUTURE WORK}

Not all combinations of materials and environment will result in environment-assisted cracking. Subcritical crack growth will result at stress intensity values close to the fracture toughness of the material in any environment. Future work is recommended to further refine the environment-assisted crack threshold of Ti $6 \mathrm{Al}-4 \mathrm{~V}$ tanks when exposed to AF-M315E. Additional testing of the bulk material between stress intensities in the range of 22-35 ksivin and weld material in the range of 33-49 ksivin will result in an increased factor of safety for the safe-life analysis of GPIM flight tanks.

\section{ACKNOWLEDGMENTS}

Authors would like to thank Tim Smith of NASA Marshall Space Flight Center; Amy Brown of Ball Aerospace; Walter Tam and Richard Bahng of Orbital ATK; Paul Zuttarelli, Adam Brand, and Jeffrey Jacobs at Edwards Air Force Base for all programmatic and testing support.

\section{REFERENCES}

1. NASGRO, Southwest Research Institute, San Antonio, Texas.

2. Lewis, C.J. and Kenny, J.T. Sustained Load Crack Growth Design Data for Ti-6AI-4V

Titanium Alloy Tanks Containing Hydrazine, AIAA/SAE 12th Propulsion Conference. AIAA Paper No. 76-769, 1976

3. Hertzberg R. W., Deformation and Fracture Mechanical of Engineering Materials, 4th ed., John Wiley \& Sons, Inc., 1996, pp 342-343 